\title{
Epq Incentive Model for Manufacture - Buyer with Floor Space and Inventory Level Constraints
}

\author{
M. Haj Meeral, M. K. Vediappan, P. Muniappan, G. Rasitha Banu
}

\begin{abstract}
This paper researches maker and purchaser creation model for deteriorating items with floor space and stock level imperative. Lagrange's multiplier procedure is utilized to take care of this sort of issue. Coordinated framework cost is created for equivalent advantages of both purchaser and producer. So as to decrease the complete stock cost, ideal request amount is resolved and furthermore floor space and stock level requirement ought to be fulfilled. Numerical model is likewise giving to revels the model.
\end{abstract}

Keywords: Production, Inventory, Order quantity, Constraints.

\section{INTRODUCTION}

In the greater part of the enterprises, request is questionable and hard to conjecture. Thus Ordering in right amounts at opportune time is constantly a pivotal issue. In this examination the creators present a model for deciding the requesting strategy which will limit the all out stock expense. The financial creation amount is a notable and generally utilized stock control system. The flawed quality and deficient things are either to be adjusted momentarily and kept in stock or dismissed at an expense.

Sana [11] examined economic production lot size model in a defective creation framework. Khan et al. [5] investigated EOQ for things with imperfect quality and assessment mistakes. J. T. Hsu and L. F. Hsu [3] considered two EPQ models with imperfect creation forms, inspection errors, and deals returns. Chang et al. [2] created effects of inspection errors and exchange credits on the financial request amount model for things with defective quality. Tiwari et al. [12] dissected effect of exchange credit and swelling on retailer's requesting strategies for non-prompt falling apart things in a two-warehouse condition. Ravithammal et al. [8] considered EOQ stock model utilizing mathematical technique with stock level imperative. Muniappan et al. [6] considered incorporated stock model for multi-echelon multi-requirements with amount markdown and coordination utilizing Lagrange multiplier system. Jenneth et al. [4] created manufacturer - buyer coordination stock

Revised Manuscript Received on December 5, 2019.

M. Haj Meeral, Assistant Professor, Department of Mathematics, the Quaide Milleth College for Men, Chennai - 600100, Tamil Nadu, India.

M. K. Vediappan, Assistant Professor, Department of Mathematics, Vels Institute of Science, Technology and Advanced Studies, Chennai -600117, Tamil Nadu, India.

P. Muniappan, Assistant Professor, Department of Mathematics, Sathyabama Institute of Science and Technology, Chennai - 600119, Tamil Nadu, India.

G. Rasitha Banu, Assistant Professor, Department of Health Informatics, FPHTM, Jazan University, KSA.

* Corresponding author: mail: mkvediappan@gmail.com model with screening procedure and deficiencies. Vediappan et al. [13] examined incorporated coordination stock model for purchaser and seller utilizing Lagrange multiplier method.

Muniappan et al. [7] considered EPQ motivating force stock model for deteriorating items including partially backlogged deficiencies. Ravithammal et al. [9] created stock model for value rebate with lack, back ordering and rework. Babu et al. [1] examined brought together generation stock model for purchaser - seller with amount markdown for fixed life time items. Ravithammal et al. [10] examined ideal estimating stock model for decaying things with positive exponential capacity of value markdown pace of interest.

\section{ASSUMPTIONS AND NOTATIONS}

The model use the following notations and assumptions

\section{Notations}

D Demand rate

$P \quad$ Production rate

$\mathrm{R}_{1} \quad$ Ordering cost for buyer

$\mathbb{R}_{2} \quad$ Setup cost for manufacturer

p Purchase cost for buyer

Q Economic Order quantity

$\mathrm{H}_{\mathrm{b}} \quad$ Holding cost for buyer

$\mathrm{H}_{\mathrm{W}} \quad$ Holding cost for manufacturer

$\mathrm{s}_{\mathrm{c}} \quad$ Screening cost for manufacturer

m Manufacturer multiples of order

$\mathrm{k} \quad$ Buyer's multiples of order

$\mathrm{d}(\mathrm{k})$ Discount factor

F $\quad$ Space involved per item

$Z \quad$ Total accessible storage space

W Maximum available stock

\section{Assumptions}

(i) Demand rate is constant

(ii) Manufacturer delivered the item and purchaser has no shortage and furthermore manufacturer gives the quantity discount to the purchaser.

(iii) The lot size Q doesn't surpasses the warehouse capacity and accessible inventory level.

(iv) Mathematically, the constraints will be written as $F Q \leq X$ and $\frac{Q}{2} \leq W$

\section{MODEL FORMULATION}

The total buyer cost have ordering cost, holding cost and screening cost and manufacturer have setup 
cost, holding cost, discount factor for buyer.

Additionally manufacturer creates the item and gives the quantity discount to the purchaser.

The total cost for buyer and manufacturer will be written as $\mathrm{TC}_{\mathrm{b}}=\frac{\mathrm{DR}_{1}}{\mathrm{Q}}+\frac{\mathrm{QH}_{\mathrm{b}}}{2}+\frac{\mathrm{Qs}_{\mathrm{E}}}{2}$

$\mathrm{TC}_{\mathrm{m}}=\frac{\mathrm{DR}_{2}}{\mathrm{kmQ}}+\frac{\mathrm{kmQH}_{\mathrm{q}}}{2}\left(1-\frac{\mathrm{D}}{\mathrm{p}}\right)+\mathrm{pDd}(\mathrm{k})$

Integrated system cost can be written as

$\mathrm{TC}_{\mathrm{s}}=\mathrm{TC}_{\mathrm{b}}+\mathrm{TC}_{\mathrm{m}}$

$\mathrm{TC}_{g}=\frac{1}{\mathrm{Q}}\left(\mathrm{DR}_{1}+\frac{\mathrm{DR}_{2}}{\mathrm{~km}}\right)+\frac{\mathrm{Q}}{2}\left(\mathrm{H}_{\mathrm{b}}+\mathrm{s}_{\mathrm{c}}\right)+\frac{\mathrm{kmQH}_{\mathrm{v}}}{2}\left(1-\frac{\mathrm{D}}{P}\right)+\mathrm{pDd}(\mathrm{k})$

subject to $F Q \leq X$

$$
\frac{Q}{2} \leq W
$$

Here, we consider the warehouse capacity constraint and inventory level constraint. Now, Lagrange multiplier functions $\alpha$ and $\lambda$ is added on integrated system cost and it can be written as follows:

$\mathrm{TC}_{s}=\frac{1}{\mathrm{Q}}\left(\mathrm{DR}_{1}+\frac{\mathrm{DR}_{2}}{\mathrm{~km}}\right)+\frac{\mathrm{Q}}{2}\left(\mathrm{H}_{\mathrm{b}}+\mathrm{s}_{\mathrm{Q}}\right)+\frac{\mathrm{kmQH}_{w}}{2}\left(1-\frac{\mathrm{D}}{p}\right)+$
$\mathrm{pDd}(\mathrm{k})+\omega(\mathrm{FQ}-\mathrm{X})+\lambda\left(\frac{\mathrm{Q}}{2}-\mathrm{W}\right)$

(2)

Equation (2) can be written as

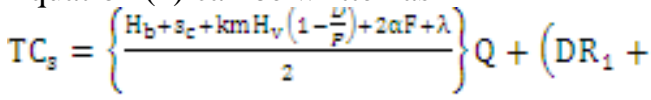

$\left.\frac{\mathrm{DR}_{2}}{\mathrm{mk}}\right) \frac{1}{\mathrm{Q}}+\mathrm{pDd}(\mathrm{k})-\alpha \mathrm{X}-\lambda \mathrm{W}$

It is of the form $a_{1} Q+\frac{a_{2}}{Q}+a_{n}$.

$\mathrm{Q}$ will be taken as, $\mathrm{Q}=\sqrt{\frac{a_{2}}{a_{1}}}$

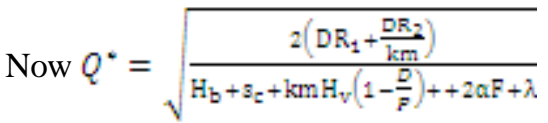

where

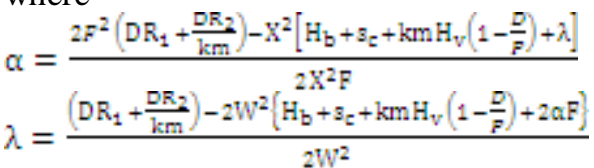

\section{NUMERICAL EXAMPLE}

1. Let $\mathbb{R}_{1}=300, R_{2}=900, D=1000, P=2000, H_{v}=0.05$, $\mathrm{H}_{\mathrm{b}}=0.03, \mathrm{~s}_{\mathrm{c}}=0.3, \mathrm{p}=0.5, \mathrm{~m}=4, \mathrm{k}=3, \mathrm{~d}(\mathrm{k})=30 \%$, $\mathrm{X}=4000, \mathrm{~W}=800, \alpha=0.3, \lambda=0.2, \mathrm{~F}=2$.

The optimal solutions are

$\mathrm{Q}^{*}=1600, \mathrm{TC}_{\mathrm{b}}=451.50, \mathrm{TC}_{\mathrm{v}}=436.88$,

$\mathrm{TC}_{g}=1.0169 \mathrm{X}^{\mathrm{g}}$ satisfies the constraints $F \mathrm{Q} \leq 4000$ and $\frac{\mathrm{Q}}{2} \leq 800$

2. Let $R_{1}=200, R_{2}=1000, D=1200, P=2000, H_{v}=0.04$, $\mathrm{H}_{\mathrm{b}}=0.02, \mathrm{~s}_{\mathrm{c}}=0.4, \mathrm{p}=0.6, \mathrm{~m}=4, \mathrm{k}=3, \mathrm{~d}(\mathrm{k})=40 \%$, $\mathrm{X}=3000, \mathrm{~W}=600, \alpha=0.3, \lambda=0.2, \mathrm{~F}=2$.

The optimal solutions are

$Q^{*}=1200, T_{b}=452, T_{y}=486.53$,

$\mathrm{TC}_{\mathrm{g}}=1.0150 \mathrm{X} 10^{\mathrm{g}}$ satisfies the constraints $\mathrm{FQ} \leq 3000$ and $\frac{Q}{2} \leq 600$

\section{CONCLUSION}

In this exploration an EPQ stock model is produced for organizing production network for purchaser maker incorporated framework. Maker makes the thing and gives the amount rebate to the buyer. Besides, the model fulfills both floor space and stock level constraints. A numerical model is figured under this circumstances and Lagrangian multiplier strategy is utilized to tackle this sort of issues. For future research, models can be created by considering the components like price discount policy, onetime discount, trade credit and so on.,

\section{REFERENCES}

1. Gfor Fixed Life Time Products", Jour of Adv Research in Dynamical \& Control Systems, 11, (1), 2019, 288 - 291.

2. C. T. Chang, M. C. Cheng and P.Y. Soong, "Impacts of inspection errors and trade credits on the economic order quantity model for items with imperfect quality", International Journal of Systems Science: Operations \& Logistics, 3(1), 2016, 34-48.

3. J. T. Hsu and L.F. Hsu, "Two EPQ models with imperfect production processes, inspection errors, planned backorders, and sales returns", Computers \& Industrial Engineering, 64(1), 2013, 389-402.

4. A. Jenneth, M. K. Vediyappan and M. Babu, "Manufacturer - Buyer coordination inventory model with screening process and shortages", International Journal of Scientific Research and Review, 8, (3), 2019,122-125.

5. M. Khan, M. Y. Jaber and M. Bonney, "An economic order quantity (EOQ) for items with imperfect quality and inspection errors", International Journal of Production Economics, 133(1), 2011, 113-118

6. P. Muniappan, R. Uthayakumar and S. Ganesh, "Integrated inventory model for multi-echelon multi-constraints with quantity discount and coordination supply chain by using Lagrange multiplier technique", Asia Life Science, 14,(2017), 33-42.

7. P. Muniappan, M. Ravithammal, and A. Ameenammal, "EPQ incentive inventory model for deteriorating products involving partially backlogged shortages", Jour of Adv Research in Dynamical \& Control Systems, 10(6), (2018), 940-943.

8. M. Ravithammal, P. Muniappan and S. Hemamalini, "EOQ inventory model using algebraic method with inventory level constraint", Journal of International Pharmaceutical Research, 46(1), (2019), 813-815.

9. M. Ravithammal, R. Uthayakumar and S. Ganesh, "Obtaining inventory model for price discount with shortage, back ordering and rework", Asia Life Science, 14, (2017), 25-32.

10. M. Ravithammal, P. Muniappan and R. Uthayakumar, "An Optimal Pricing Inventory Model for Deteriorating Items with Positive Exponential Function of Price Discount Rate of demand", Jour of Adv Research in Dynamical \& Control Systems, 10(5), (2018), 639-645.

11. S. S. Sana, "An economic production lot size model in an imperfect production system", European Journal of Operational Research, 201(1), 2010, 158-170.

12. S. Tiwari, L. E. Cárdenas-Barrón, A. Khanna, and C. K. Jaggi, "Impact of trade credit and inflation on retailer's ordering policies for non-instantaneous deteriorating items in a two-warehouse environment", International Journal of Production Economics, 176, 2016, 154-169.

13. M. K. Vediappan, M. Ravithammal and P. Muniappan, "Integrated Coordination Inventory Model for Buyer - Vendor Using Lagrange Multiplier Technique", Jour of Adv Research in Dynamical \& Control, $11,(1), 2019,283-287$. 